\title{
Metacercariae of Clinostomum schizothoraxi Kaw, 1950 (Digenea: Clinostomatidae) in Carassius carassius (Linnaeus) under different environmental conditions
}

\author{
Humaira Bashir Shah ${ }^{1}$, Abdul R. Yousuf ${ }^{1}$, Mohammad Z. Chishti ${ }^{1}$ and Fayaz Ahmad ${ }^{2}$ \\ ${ }^{1}$ Limnology and Fisheries Laboratory, Centre of Research for Development, University of Kashmir, Srinagar, India; \\ ${ }^{2}$ Parasitology Research Laboratory, Post Graduate Department of Zoology, University of Kashmir, Srinagar, India
}

\begin{abstract}
This report addresses the possible impacts of local habitat characteristics on the metacercariae of Clinostomum schizothoraxi Kaw, 1950 infecting crucian carp, Carassius carassius (Linnaeus), from three lakes in Kashmir. The lakes chosen encompass an extremely wide gradient in trophic status - Manasbal (less polluted and mesotrophic), Dal (moderately polluted and eutrophic) and Anchar (strongly polluted and hypertrophic). The results indicate that infrapopulation-level descriptors of abundance of C. schizothoraxi in fish differed between the three lakes and revealed that the infection levels were greater at Anchar Lake. Furthermore, the prevalence, mean abundance and mean intensity of infection also changed during the period of investigation along the seasonal gradient of water temperature. The fact that the abundance patterns of the parasite differed in different populations of the same host provided a unique opportunity for a comparative study on the temporal variations in infection patterns attained during different seasons. In particular, the lake environments showed a high degree of variability in the density profiles of mollusc intermediate hosts and, thus, the differences in the infection status of crucian carp were derived on the basis of intermediate host population size which, in turn, was influenced by the trophic characteristics of the three lakes.
\end{abstract}

Keywords: metacercariae, Clinostomum schizothoraxi, molluscs, Carassius carassius, Kashmir Himalayan lakes, eutrophication

Trophic status of lake environments in Kashmir Himalayas has been highlighted through studies on the composition and population densities of the planktonic and benthic fauna, and well supported by the assessments on principal physical and chemical parameters of the water. In fact, the variations of some environmental conditions following natural or anthropogenic stress (e.g. increase of the nutrient concentrations) often influence the population densities of lake biota that quickly respond to environmental change (Wetzel 2001).

Larval stages of digeneans infecting fish are in no way the exception and their abundance patterns may vary due to alterations in the host environmental conditions (Wisniewski 1958, Esch 1971, Chubb 1979). Various studies have suggested that changes in population densities of some larval fish trematodes can be correlated with changes in abiotic characteristics and population densities of the snail intermediate hosts (Marcogliese et al. 2001, Sandland et al. 2001, Flores and Semenas 2002, Ondračková et al. 2004, Lafferty et al. 2005, Johnson et al. 2010).

In the present study, we attempt to assess the role of local habitat characteristics on the abundance patterns of metacercariae of Clinostomum schizothoraxi Kaw, 1950 infecting Carassius carassius (Linnaeus) from three lakes in Kashmir. The results might allow us to draw inferences for the state of water quality of lakes of the region and on their trophic status by observing variations in the infection patterns of larval parasites.

\section{MATERIALS AND METHODS}

Studies were carried out in three lakes of differing pollution status in Kashmir, namely Lake Manasbal (34 $144^{\prime} 38^{\prime \prime}-$

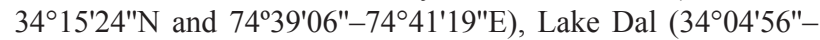
$34^{\circ} 08^{\prime} 57^{\prime \prime} \mathrm{N}$ and $\left.74^{\circ} 49^{\prime} 48^{\prime \prime}-74^{\circ} 52^{\prime} 51^{\prime \prime E}\right)$ and Lake Anchar $\left(34^{\circ} 07^{\prime} 31^{\prime \prime}-34^{\circ} 10^{\prime} 11^{\prime \prime} \mathrm{N}\right.$ and $\left.74^{\circ} 46^{\prime} 23^{\prime \prime}-74^{\circ} 48^{\prime} 00^{\prime \prime} \mathrm{E}\right)$. Whilst two lakes, Anchar and Dal, have been subject to ever-increasing cultural eutrophication and have been categorized as hypertrophic and eutrophic, respectively, Lake Manasbal is mesotrophic (Zutshi et al. 1980, Pandit and Yousuf 2002). The temperature of the water varied $2-30{ }^{\circ} \mathrm{C}$ (annual average $18.6 \pm 8.3^{\circ} \mathrm{C}$ ) in Lake Manasbal, $5.5-29^{\circ} \mathrm{C}$ (annual average $18.1 \pm 7.5^{\circ} \mathrm{C}$ ) in Lake Dal and $5-28^{\circ} \mathrm{C}$ (annual average $16.9 \pm 6.5^{\circ} \mathrm{C}$ ) in Lake Anchar. Moreover, the surface water temperature showed seasonal fluctuation with minimum temperatures recorded in winter months and maximum in summer months (Table 1). The mean temperatures recorded in Lake Anchar were generally comparatively lower than those of lakes Dal and Manasbal on most occasions. Throughout the course of this study (June 2006 to May 2008), 
Table 1. Temporal variations in water temperature $\left({ }^{\circ} \mathrm{C}\right)$ recorded in Manasbal, Dal, and Anchar lakes (values are expressed as mean $\pm \mathrm{SD}$ ).

\begin{tabular}{|c|c|c|c|}
\hline Month & Manasbal & Dal & Anchar \\
\hline \multicolumn{4}{|l|}{2006} \\
\hline June & $29.0 \pm 0.5$ & $26.0 \pm 0.3$ & $23.9 \pm 1.5$ \\
\hline July & $29.3 \pm 0.8$ & $27.9 \pm 0.4$ & $23.9 \pm 3.1$ \\
\hline August & $28.3 \pm 1.6$ & $27.6 \pm 0.4$ & $24.0 \pm 2.1$ \\
\hline September & $23.0 \pm 2.2$ & $22.5 \pm 0.8$ & $18.6 \pm 1.1$ \\
\hline October & $16.7 \pm 2.7$ & $16.2 \pm 1.0$ & $15.5 \pm 1.2$ \\
\hline November & $12.2 \pm 1.1$ & $10.8 \pm 0.7$ & $16.3 \pm 0.6$ \\
\hline December & $7.4 \pm 0.7$ & $7.2 \pm 1.4$ & $11.5 \pm 4.6$ \\
\hline \multicolumn{4}{|l|}{2007} \\
\hline January & $8.7 \pm 1.3$ & $6.3 \pm 1.0$ & $7.7 \pm 2.0$ \\
\hline February & $10.2 \pm 0.4$ & $13.5 \pm 1.8$ & $11.4 \pm 0.7$ \\
\hline March & $20.1 \pm 0.8$ & $16.1 \pm 1.3$ & $15.2 \pm 1.4$ \\
\hline April & $24.5 \pm 3.2$ & $19.8 \pm 1.3$ & $17.1 \pm 3.8$ \\
\hline May & $21.9 \pm 0.7$ & $23.9 \pm 0.4$ & $22.8 \pm 2.0$ \\
\hline June & $29.3 \pm 0.4$ & $26.3 \pm 0.7$ & $24.5 \pm 2.0$ \\
\hline July & $27.8 \pm 1.3$ & $27.6 \pm 0.9$ & $23.5 \pm 3.3$ \\
\hline August & $28.2 \pm 1.3$ & $26.6 \pm 0.5$ & $23.9 \pm 1.4$ \\
\hline September & $23.6 \pm 1.4$ & $23.3 \pm 1.0$ & $23.0 \pm 1.2$ \\
\hline October & $18.6 \pm 1.6$ & $16.8 \pm 1.1$ & $15.6 \pm 0.9$ \\
\hline November & $8.9 \pm 1.0$ & $8.0 \pm 0.6$ & $5.8 \pm 0.6$ \\
\hline December & $6.8 \pm 0.4$ & $8.6 \pm 0.2$ & $7.5 \pm 0.9$ \\
\hline \multicolumn{4}{|l|}{2008} \\
\hline January & $3.6 \pm 1.1$ & $6.1 \pm 0.4$ & $6.2 \pm 0.6$ \\
\hline February & $8.7 \pm 0.3$ & $11.1 \pm 0.7$ & $10.1 \pm 0.7$ \\
\hline March & $16.2 \pm 0.8$ & $17.9 \pm 0.5$ & $19.1 \pm 0.2$ \\
\hline April & $20.6 \pm 0.7$ & $20.3 \pm 0.4$ & $21.9 \pm 0.4$ \\
\hline May & $22.9 \pm 1.8$ & $23.3 \pm 2.0$ & $16.8 \pm 3.6$ \\
\hline
\end{tabular}

the highly eutrophic Lake Anchar was characterized by elevated total phosphorus (TP) and dissolved inorganic nitrogen (DIN) levels with low transparency and shallow depth (Table 2). TP and DIN are considered the key elements in enhancing and accelerating the eutrophic conditions (Wetzel 2001). Transparency and depth recorded at Lake Manasbal were higher with low levels of TP and DIN (Table 2). More details on the limnology of these systems are presented in Shah (2010).

Water samples for physico-chemical analyses were analyzed by following standard procedures as established by APHA (1998). The measurements of surface water temperatures were made by a mercury thermometer of $0-50{ }^{\circ} \mathrm{C}$ range and $0.1^{\circ} \mathrm{C}$ precision. Depth was determined with a graduated non-stretchable line, and transparency with a Secchi disc. Total phosphorus was determined by stannous chloride colorimetric method after following double acid (sulphuric acid-nitric acid) digestion method. Furthermore, dissolved inorganic nitrogen (nitrate, nitrite and ammonia combined) was also determined by colorimetric methods. Dissolved oxygen was determined by azide modification of Winkler's method, and conductivity was measured by a digital conductivity meter. In each lake, sampling was undertaken at five sampling points, to ensure unbiased characterization, with latitudinal and longitudinal data for each site being recorded with a hand-held global positioning system (GPS). Collectively the sites span the different regions of the lakes. They are labeled M1-M5 (Lake Manasbal), D1-D5 (Lake Dal) and A1-A5 (Lake Anchar). A brief description of these sites is given below:
Table 2. Physico-chemical characteristics of the three study lakes (values are expressed as mean $\pm \mathrm{SD}$ ).

\begin{tabular}{lccc}
\hline Parameter & Manasbal & Dal & Anchar \\
\hline Transparency $(\mathrm{m})$ & $3.3 \pm 0.7$ & $1.9 \pm 0.4$ & $1.1 \pm 0.6^{*}$ \\
Maximum depth $(\mathrm{m})$ & $11.7 \pm 0.5$ & $2.3 \pm 0.3$ & $1.4 \pm 0.5^{*}$ \\
$\begin{array}{l}\text { Dissolved inorganic nitrogen } \\
(\mu \mathrm{g} / \mathrm{l})\end{array}$ & $153 \pm 93$ & $310 \pm 291$ & $1291 \pm 1215^{*}$ \\
Total phosphorus $(\mu \mathrm{g} / \mathrm{l})$ & $230 \pm 103$ & $282 \pm 150$ & $752 \pm 559^{*}$ \\
Dissolved oxygen $(\mathrm{mg} / \mathrm{l})$ & $6.1 \pm 0.8$ & $5.4 \pm 1.5$ & $2.2 \pm 1.0^{*}$ \\
Lymnaeid snails (organisms $\left./ \mathrm{m}^{2}\right)$ & $130 \pm 32$ & $192 \pm 46$ & $405 \pm 223^{*}$ \\
\hline
\end{tabular}

* Differences between values significant at $\mathrm{P}<0.05$

\section{Lake Manasbal}

M1 (34 $\left.15^{\prime} 07^{\prime \prime} \mathrm{N}, 74^{\circ} 41^{\prime} 07^{\prime \prime} \mathrm{E}\right)$ : It is located close to the eastern bank of the lake at a distance of $10 \mathrm{~m}$ away from the place where Laar Kol (a small irrigational channel) drains into the lake. The maximum depth at this site was $1.65 \mathrm{~m}$.

M2 (34 $\left.14^{\prime} 58^{\prime \prime} \mathrm{N}, 74^{\circ} 40^{\prime} 52^{\prime \prime} \mathrm{E}\right)$ : It is located just adjacent to the village of Koondabal at a distance of $20 \mathrm{~m}$ away from the shore. The maximum depth at this site was $2.3 \mathrm{~m}$.

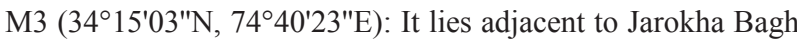
at a distance of $10 \mathrm{~m}$ away from the shore. The maximum depth at this site was $1.5 \mathrm{~m}$.

M4 (34 $\left.14^{\prime} 56^{\prime \prime} \mathrm{N}, 74^{\circ} 39^{\prime} 43^{\prime \prime} \mathrm{E}\right)$ : It is situated near the deepest part of the lake. The maximum depth recorded at this site was $12.2 \mathrm{~m}$.

M5 (34 $\left.14^{\prime} 52^{\prime \prime} \mathrm{N}, 74^{\circ} 39^{\prime} 22^{\prime \prime} \mathrm{E}\right)$ : It lies near the exit of lake on the western side. The maximum depth at this site was $1.0 \mathrm{~m}$.

\section{Lake Dal}

D1 $\left(34^{\circ} 08^{\prime} 41^{\prime \prime} \mathrm{N}, 74^{\circ} 50^{\prime} 58^{\prime \prime} \mathrm{E}\right)$ : It is located towards the northwest side adjacent to the place where Telbal Stream enters the lake. The maximum depth at this site was $0.8 \mathrm{~m}$.

D2 $\left(34^{\circ} 08^{\prime} 06^{\prime \prime} \mathrm{N}, 74^{\circ} 50^{\prime} 33^{\prime \prime} \mathrm{E}\right)$ : It is located towards the western side at a distance of about $10 \mathrm{~m}$ away from the outfall pipe of Sewage Treatment Plant near Naseem Bagh. The maximum depth at this site was $2.3 \mathrm{~m}$.

D3 $\left(34^{\circ} 07^{\prime} 59^{\prime \prime} \mathrm{N}, 74^{\circ} 51^{\prime} 06^{\prime \prime} \mathrm{E}\right)$ : It lies near the central part of the basin, very close to Sonalank Island. The maximum depth at this site was $3.0 \mathrm{~m}$.

D4 $\left(34^{\circ} 07^{\prime} 32^{\prime \prime} \mathrm{N}, 74^{\circ} 50^{\prime} 51^{\prime \prime E}\right)$ : It is located just adjacent to Akhoon Mohalla in the western part of the basin. The maximum depth at this site was $2.4 \mathrm{~m}$.

D5 (340' $\left.54^{\prime \prime} \mathrm{N}, 74^{\circ} 50^{\prime} 20^{\prime \prime} \mathrm{E}\right)$ : It lies within the floating gardens just near the exit of Hazratbal basin into Nageen basin towards western side of the lake. The maximum depth at this site was $2.1 \mathrm{~m}$

\section{Lake Anchar}

A1 $\left(34^{\circ} 09^{\prime} 02^{\prime \prime} \mathrm{N}, 74^{\circ} 47^{\prime} 40^{\prime \prime} \mathrm{E}\right)$ : The site is situated on the northeast of the lake near the entrance of feeding channel of the Sindh stream into the lake proper. The maximum depth at this site was $1.5 \mathrm{~m}$.

A2 $\left(34^{\circ} 08^{\prime} 53^{\prime \prime} \mathrm{N}, 74^{\circ} 47^{\prime} 35^{\prime \prime} \mathrm{E}\right)$ : It is located towards the northeast of the lake about $80 \mathrm{~m}$ away from Ghat near Jenab Sahib Mosque, Soura. The maximum depth recorded at this site was $1.0 \mathrm{~m}$. 
A3 $\left(34^{\circ} 08^{\prime} 47^{\prime \prime} \mathrm{N}, 74^{\circ} 47^{\prime} 22^{\prime \prime} \mathrm{E}\right)$ : It lies at the centre of the open water area. The maximum depth at this site was $2.0 \mathrm{~m}$.

A4 ( $\left.34^{\circ} 08^{\prime} 16^{\prime \prime} \mathrm{N}, 74^{\circ} 47^{\prime} 31^{\prime \prime} \mathrm{E}\right)$ : It is located adjacent to the marshland southeast to the lake at the confluence point where the effluents coming from the Sher-e-Kashmir Institute of Medical Sciences (SKIMS) and adjacent human settlement are mixed with lake water. The maximum depth at this site was $1.9 \mathrm{~m}$.

A5 $\left(34^{\circ} 08^{\prime} 26^{\prime \prime} \mathrm{N}, 74^{\circ} 46^{\prime} 24^{\prime \prime} \mathrm{E}\right)$ : It lies near the exit of lake into Shalbugh wetland near the village of Sangam. The maximum depth at this site was $2.3 \mathrm{~m}$.

The fish host studied was crucian carp, Carassius carassius and it was selected on the basis of its common occurrence in all three localities (Yousuf et al. 2002). In addition, the success of this exotic fish over the endemic ones has been attributed to its tolerance to eutrophic and hypoxic habitats. A total of 457 specimens of crucian carp (Manasbal, $\mathrm{n}=160$; Dal, $\mathrm{n}=137$; Anchar $\mathrm{n}=160$ ) were examined for metacercariae of Clinostomum schizothoraxi from June 2006 to May 2008 on a monthly basis within a five-day period. Fish samples of comparable size-class were obtained from the catches of local fishermen over a short time frame (two-day interval) to minimize temporal variability between interlake samplings. Since host body size and sample size represent key determinants of parasitism, we sought to eliminate the influence of these factors by using a comparable sample size for each locality and selecting individuals of approximately equal body size. The fish used in this study had a mean total length of $14.1 \pm 1.9 \mathrm{~cm}$. The mean length of the fish used from each lake was $13.4 \pm 1.7 \mathrm{~cm}$ (Manasbal), $14.1 \pm 1.8 \mathrm{~cm}$ (Dal) and $14.4 \pm 1.9 \mathrm{~cm}$ (Anchar). Fish were examined for encysted metacercariae of C. schizothoraxi according to the protocol adopted from Weesner (1960) and Schmidt (1992). The entire outer surface, especially the oral region, the gills and opercula, and the fins, were searched carefully for encysted trematodes. The pharyngeal cavity was dissected to recover the metacercariae and their number was recorded. For identification of parasites, papers by Kaw (1950) and Fayaz and Chishti (2000) were consulted.

In view of the fact that the transmission of trematode infections in a water body is affected by the occurrence and density of intermediate snail hosts (Ondračková et al. 2004), a follow-up study was conducted during the second year (June 2007 to May 2008) to examine the density profiles of intermediate mollusc hosts in the three lakes. To measure the variation in density of gastropod snails, five substrate hauls were taken monthly from each lake. Sampling and quantitative enumeration were done in accordance with standard methods (APHA 1998). In brief, the sediment samples were taken using a $15 \times 15 \mathrm{~cm}$ Ekman grab. The samples were washed on a screen (U.S. Standard No. 30 sieve) with $0.595 \mathrm{~mm}$ openings.

The material retained on the sieve was sorted for molluscs and number of individuals was counted. Organisms were identified using the keys outlined in Pennak (1978) and the pooled composition of the five samples was calculated. The result was expressed as the number of organisms $/ \mathrm{m}^{2}$ of the lake area. Since numerical abundance is commonly used in community ecology as a measure of the local dominance or success of species (Preston 1962) and also has precedence in population biology as the most natural measure of demography (Volterra 1926), it was decided to use numerical abundance rather than biomass as an estimator of density. Although biomass is considered a more
Table 3. Infection indices (mean $\pm \mathrm{SD}$ ) of Clinostomum schizothoraxi in Carassius carassius in the three study lakes.

\begin{tabular}{llll}
\hline Parameter/Lake & Manasbal & Dal & Anchar \\
\hline Prevalence (\%) & 14.4 & 41.6 & 57.5 \\
Mean abundance & $3.3 \pm 0.5$ & $4.9 \pm 1.7$ & $10.2 \pm 9.6$ \\
Mean intensity & $0.5 \pm 2.1$ & $2.0 \pm 2.8$ & $5.9 \pm 15.0$ \\
\hline
\end{tabular}
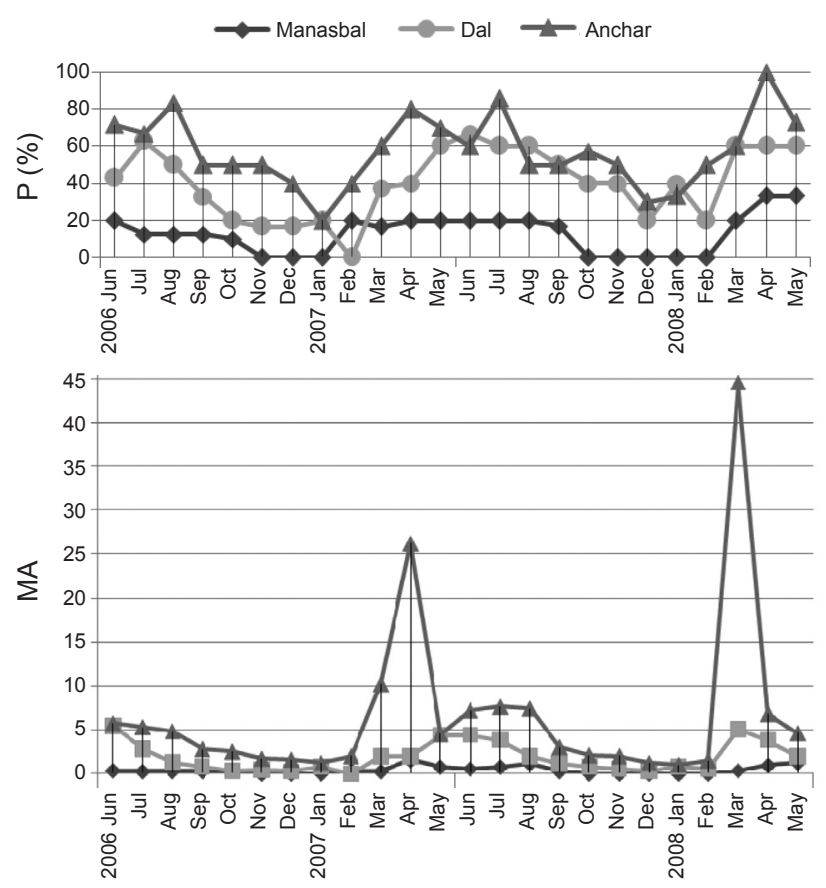

Fig. 1. Monthly variations in prevalence - P $(\%)$ and mean abundance - MA of Clinostomum schizothoraxi in Carassius carassius from Manasbal, Dal, and Anchar lakes.

useful abundance measure than numerical abundance, it is more specifically used to reveal the relative abundance of species within communities (Morlon et al. 2009).

Three common infrapopulation-level descriptors of parasite abundance, i.e. prevalence (proportion of infected hosts in percent), mean intensity (number of parasites per infected host individual) and mean abundance (number of parasites per host individuals examined), were calculated according to Bush et al. (1997). The SPSS software (Statistical Package for Social Science) version 12.0 for Windows was employed for statistical analyses. Since parasite distributions were generally aggregated, i.e. variance-to-mean ratios were greater than 1, non-parametric Kruskal-Wallis one-way analysis of variance (ANOVA) was employed to detect significant differences in infection patterns between the lakes and Mann-Whitney U test was used for pairwise comparisons. Correlations were assessed using Spearman rank correlation coefficients. The significance of all statistical analyses was established at $\mathrm{P}$ values $<0.05$ unless otherwise stated.

\section{RESULTS}

Metacercariae of Clinostomum schizothoraxi were recorded in all the three lakes. A comparison of infection indices at the polluted Lake Anchar and other sites 

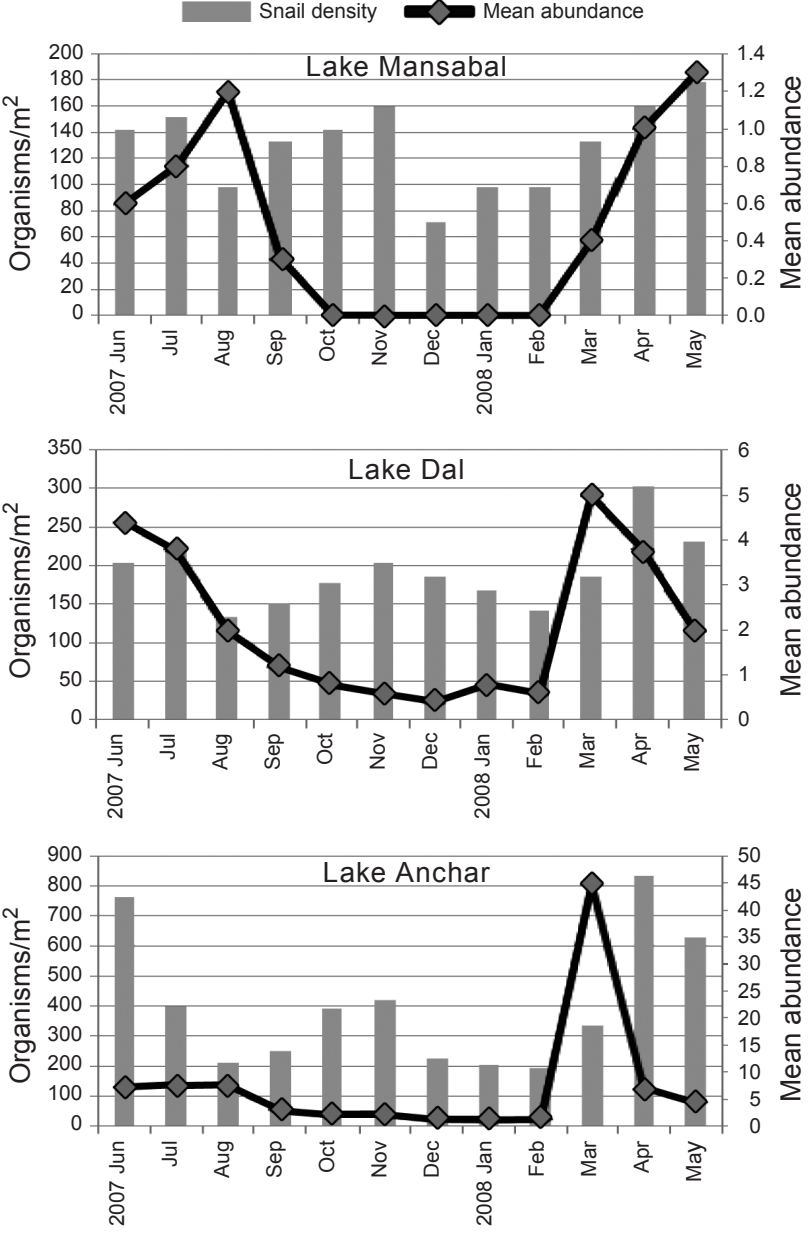

Fig. 2. Monthly variations in snail density (organisms $/ \mathrm{m}^{2}$ ) and mean abundance of Clinostomum schizothoraxi in Carassius carassius in Manasbal, Dal, and Anchar lakes.

revealed that the infestation was greater at the former (Table 3). The prevalence, mean abundance and mean intensity of infection changed during the period of investigation. The monthly prevalences in the three lakes had their highest values in summer in most cases (Fig. 1) and the interlake differences in prevalence of infection were highly significant (Kruskal-Wallis test, $\mathrm{H}=40.373$, $\mathrm{df}=2$, $\mathrm{P}<0.001)$. The prevalence values at Lake Anchar were significantly higher than those at lakes Dal and Manasbal (Mann-Whitney $\mathrm{U}$ test, $\mathrm{U}=164.5, \mathrm{P}=0.010$ and $\mathrm{U}=9$, $\mathrm{P}<0.001$, respectively).

A significant positive correlation was observed between water temperature and mean abundance at all the three localities $\left(\mathrm{r}_{\mathrm{S}}=0.712, \mathrm{P}<0.01\right.$ at Lake Anchar, $\mathrm{r}_{\mathrm{S}}=0.699, \mathrm{P}<0.01$ at Lake Dal and $\mathrm{r}_{\mathrm{S}}=0.638, \mathrm{P}<0.01$ at Lake Manasbal). The overdispersion index (variance-tomean ratio) was, however, highest in the hypereutrophic Lake Anchar (14.02), in which the maximum larval intensity (223 metacercariae) was recorded. In general, large values of variance-to-mean ratio were associated with large mean abundance values. In contrast, the variance-

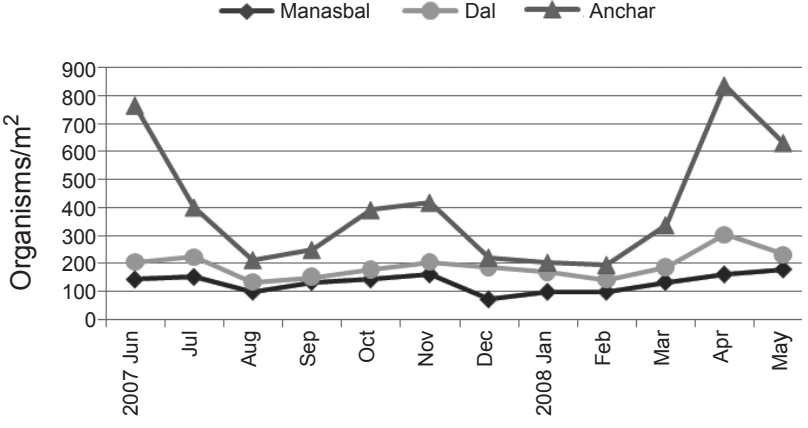

Fig. 3. Density of Lymnaea in Manasbal, Dal, and Anchar lakes.

to-mean ratio values were found to be 1.47 and 0.53 for lakes Dal and Manasbal, respectively.

The mean abundance of infection exhibited a trend between the monthly samples similar to that of the prevalence of infection (Fig. 1). There were significant differences in mean abundance among the lakes studied (Kruskal-Wallis test, $\mathrm{H}=40.020, \mathrm{df}=2, \mathrm{P}<0.001$ ). The abundance values at Lake Anchar were significantly higher than those in lakes Dal and Manasbal (Mann-Whitney $\mathrm{U}$ test, $\mathrm{U}=122.5, \mathrm{P}=0.001$ and $\mathrm{U}=10, \mathrm{P}<0.001$, respectively).

Mean intensity values showed the same pattern as for the prevalence of infection in the three localities. The differences were statistically significant $(\mathrm{H}=27.692, \mathrm{df}=2$, $\mathrm{P}<0.001)$; again, the values at Lake Anchar were higher than those at lakes Dal or Manasbal $(\mathrm{U}=131.5, \mathrm{P}=0.001$ and $\mathrm{U}=53, \mathrm{P}<0.001$, respectively).

The total mollusc density generally corresponded positively to the spring and summer recruitment of the parasites by fish (Fig. 2). The density of the entire snail guild of Lymnaea spp. is summarized in Fig. 3. The differences in Lymnaea spp. density among the lakes were evident: a greater number of organisms were present in Lake Anchar with an average of 405 snails $/ \mathrm{m}^{2}$ compared to 192 snails $/ \mathrm{m}^{2}$ in Lake Dal and 130 snails $/ \mathrm{m}^{2}$ in Lake Manasbal. The differences between the lakes were significant $(\mathrm{H}=24.476, \mathrm{df}=2, \mathrm{P}<0.001)$.

The results also indicate apparent correlations between some of the variables. A general significant positive correlation was observed between the density of snail hosts and mean abundance of parasites $\left(\mathrm{r}_{\mathrm{s}}=0.787, \mathrm{P}<0.01\right)$, total phosphorus and snail density $\left(\mathrm{r}_{\mathrm{S}}=0.754, \mathrm{P}<0.01\right)$, and dissolved inorganic nitrogen and snail density $\left(r_{S}=0.493, P<0.01\right)$ across the lakes. In contrast, a negative correlation was observed between depth and snail density $\left(\mathrm{r}_{\mathrm{S}}=-0.697, \mathrm{P}<0.01\right)$, transparency and snail density $\left(r_{S}=-0.717, P<0.01\right)$, and dissolved oxygen and snail density $\left(\mathrm{r}_{\mathrm{S}}=-0.571, \mathrm{P}<0.01\right)$.

\section{DISCUSSION}

The results from this study indicate that the total phosphorus (TP) and dissolved inorganic nitrogen (DIN) con- 
tent of the lakes correlate positively with the density of the first intermediate hosts (snails) and with the metacercarial infection levels in the second intermediate hosts (fish). Evidently, conditions in Lake Anchar seem to favour digeneans in general as the first intermediate hosts were most abundant in this water body. The high concentration of inorganic nutrients in the water and high productivity seem to provide suitable conditions for the development of dense mollusc populations.

These results agree with those of Johnson et al. (2010) in that if intermediate hosts are tolerant of (or thrive under) elevated nutrient conditions, such as some hypoxiatolerant snails, infection can respond positively to inputs of phosphorus $(\mathrm{P})$ and nitrogen $(\mathrm{N})$. This is further substantiated by the meta-analysis study by Vidal-Martínez et al. (2010). These authors concluded that the numerical response of digenean larvae to harsh water environments varies according to the type of environmental impact or pollutant: pollutants such as paper-mill effluents, crude oil, PCBs, pesticides and heavy metals impart a negative influence on the abundance of digenean metacercariae, whereas eutrophication exhibits a positive effect.

Furthermore, the digenean abundance increased concomitantly with increasing water temperature during spring and summer, and a subsequent fall occurred thereafter. According to Chubb (1979), seasonality in prevalence and abundance of larval digeneans is triggered by the increase in water temperature, which affects the emergence of cercariae from the snail intermediate hosts. The present study also revealed this relationship.

There is also some evidence in the literature that intense light and natural ultraviolet radiation impair the survival and infectivity of free-living phases of parasites. Prah and James (1977) demonstrated that UV radiation in sunlight penetrates to a maximum depth of $15 \mathrm{~cm}$ in clean, clear and still water, which, in turn, significantly shortens the life span of free swimming miracidia. If this is true, miracidia are protected to different extents in waters of different turbidity: the more turbid the waters, the less detrimental the effect of UV radiation. In nature, therefore, the effect of solar UV radiation upon miracidia in turbid waters is likely to be negligible.

Furthermore, suspended organic and inorganic matter will further reduce the depth to which the radiation penetrates. According to Rowan (1965) and Christensen et al. (1980), high cercarial counts in turbid water conditions might be due to the role of turbidity as a cover for cercariae against predation by various aquatic organisms. Such a cover probably plays an important role in cercarial dynamics in nature. These patterns indicate that water transparency plays an important role in connection with dynamics of infection by larval digeneans.

The present study confirmed that transparency and shallow depth seem to be inversely related to the density of snails and, consequently, to the abundance of larval digeneans in fish. The transparency in Lake Anchar was relatively lower due to higher turbidity compared with the other two lakes and the maximum depth recorded at the central site of the lakes varied from $2 \mathrm{~m}$ in Lake Anchar to $3 \mathrm{~m}$ in Lake Dal to $12.2 \mathrm{~m}$ in Lake Manasbal (Shah 2010).

It has been pointed out that shallow waters create excellent conditions for the survival of many intermediate hosts such as snails, the first intermediate hosts for most digeneans (Janovy and Hardin 1988), and promote retention of free-swimming infective stages such as digenean miracidia and cercariae (Marcogliese 2001). Low water levels can also result in increase in nesting habitats for certain water birds because they would be able to feed more easily upon the benthos on a regular basis (Marcogliese and Cone 1991). Thus, in Lake Anchar an increase in digenean infections in fish can be related to its shallow depth as shallow water bodies are best suited for emergent vegetation and benthic invertebrates (Wetzel 2001). The reduced water depth has been shown to induce dramatic and complex effects on factors such as water temperature, snail densities and bird densities, all affecting the cercarial transmission (Chubb 1979).

Snail density and visitation of bird definitive host often play important roles for the transmission of larval digeneans infecting fish hosts (Marcogliese et al. 2001, Sandland et al. 2001, Ondračková et al. 2004). Furthermore, the distribution and abundance of macrophytes are usually thought to be primarily a function of abiotic factors, including depth, nutrients, current, waves and light (Wetzel 2001). Due to excessive nutrient input, Lake Anchar is a highly eutrophic wetland compared to Lake Dal with prolific emergent vegetation, the most suitable of all localities for pulmonate snails such as lymnaeids (Marcogliese et al. 2001). Both of them have far higher macrophytic densities compared with Lake Manasbal. Not surprisingly, gastropod snails which use macrophytes as food source and as an oviposition substratum were more abundant in the lakes Anchar and Dal than in Lake Manasbal. The abundance of larval digeneans in fish seems to correspond to the abundance of the first intermediate host. Thus, the different density values of snails are well suited to reflect the respective degree of eutrophication in the different localities. The occurrence of larvae in the fish examined from Lake Anchar throughout the year could indicate a constant supply of infected intermediate hosts.

To conclude, the results are consistent with the hypothesis that eutrophication increases infection of fish with metacercariae of Clinostomum schizothoraxi and modulates the abundance pattern of gastropod intermediate hosts. It indeed follows from this study that differences in abundance of gastropods in lakes of different trophic status may act as litmus test for the possible existence of lake-specific differences in abundance of digenetic trematode infections in fish. Further studies are needed to un- 
derstand better the impact of eutrophication on trematode metacercariae in other lakes of the region and the suggestion developed here may provide an appropriate starting point.
Acknowledgements. We would like to thank Prof. Azra N. Kamili, Director, Centre of Research for Development (CORD), University of Kashmir, for providing laboratory facilities. Thanks are also due to all research scholars and technical staff of the Limnology and Fisheries Laboratory, and Microbiology and Pathology Laboratory, CORD for their invaluable help during field samplings.

\section{REFERENCES}

APHA 1998: Standard Methods for the Examination of Water and Wastewater. $20^{\text {th }}$ Edition. American Public Health Association. Washington, D.C., $1325 \mathrm{pp}$.

Bush A.O., Lafferty K.D., Lotz J.M., Shostak A.W. 1997: Parasitology meets ecology on its own terms: Margolis et al. revisited. J. Parasitol. 83: 575-583.

Christensen N.O., Frandsen F., Nansen P. 1980: The interaction of some environmental factors influencing Schistosoma mansoni cercarial host-finding. J. Helminthol. 54: 203-205.

Cнивв J.C. 1979: Seasonal occurrence of helminths in freshwater fishes. Part II. Trematoda. Adv. Parasitol. 17: 142-313.

Esch G.W. 1971: Impact of ecological succession on the parasite fauna in centrarchids from oligotrophic and eutrophic ecosystems. Am. Midl. Nat. 86: 160-168.

Fayaz A., Chishti M.Z. 2000: Fish trematode parasites of Kashmir Part II. Genus Clinostomum Leidy, 1856 (Digenea: Clinostomatidae). Oriental Sci. 5: 13-22.

Flores V., Semenas L. 2002: Infection patterns of Tylodelphys barilochensis and T. crubensis (Trematoda: Diplostomatidae) metacercariae in Galaxias maculatus (Osmeriformes: Galaxiidae) from two Patagonian Lakes and observations on their geographical distribution in the southern Andean region, Argentina. J. Parasitol. 88: 1135-1139.

JANOVY J. Jr., HaRdin E.L. 1988: Diversity of the parasite assemblage of Fundulus zebrinus in the Platte River of Nebraska. J. Parasitol. 74: 207-213.

Johnson P.T.J., Townsend A.R., Cleveland C.C., Glibert P.M., Howarth R.W., McKenzie V.J., Rejmankova E., Ward M.H. 2010: Linking environmental nutrient enrichment and disease emergence in humans and wildlife. Ecol. Applic. 20: 16-29.

Kaw B.L. 1950: Studies in helminthology: helminth parasites of Kashmir. Part 1 Trematoda. Ind. J. Helminthol. 2: 67-126.

Lafferty K.D., Hechinger R.F., Lorda J., Soler L. 2005: Trematodes associated with mangrove habitat in Puerto Rican salt marshes. J. Parasitol. 91: 697-699.

Marcogliese D.J. 2001: Implications of climate change for parasitism of animals in the aquatic environment. Can. J. Zool. 79: $1331-1352$

Marcogliese D.J., Compagna S., Bergeron E., McLaughlin J.D. 2001: Population biology of eyeflukes in fish from a large fluvial ecosystem: the importance of gulls and habitat characteristics. Can. J. Zool. 79: 1102-1113.

Marcogliese D.J., Cone D.K. 1991: Importance of lake characteristics in structuring parasite communities of salmonids from insular Newfoundland. Can. J. Zool. 69: 2962-2967.

Morlon H., White E., Etienne R., Green J., Ostuing A., Alonso D., Enquist B., He F., Hurlbert A., Magurran A., Maurer B., McGill B., Olff H., Storch D., Zillio T. 2009: Tak-

Received 28 February 2012 ing species abundance distributions beyond individuals. Ecol. Lett. 12: 488-501.

OndračKová M., Šimková A., Gelnar M., Jurajda P. 2004: Posthodiplostomum cuticola (Digenea: Diplostomatidae) in intermediate fish hosts: factors contributing to the parasite infection and prey selection by the definitive bird host. Parasitology 129: 761-770.

Pandit A.K., Yousuf A.R. 2002: Trophic status of Kashmir lakes as depicted by water chemistry. J. Res. Dev. 2: 1-12.

Pennak R.W. 1978: Freshwater Invertebrates of the United States. John Wiley and Sons, Inc., London, 803 pp.

Prah S.K., JAmes C. 1977: The influence of physical factors on the survival and infectivity of miracidia of Schistosoma mansoni and S. haematobium. I. Effect of temperature and ultraviolet light. J. Helminthol. 51: 73-85.

Preston F.W. 1962: The canonical distribution of commonness and rarity. Ecology 43: 185-215.

Rowan W.B. 1965: The ecology of schistosome transmission foci. Bull. WHO 33: 63-71.

Sandland G.J., Goater C.P., Danylchuk A.J. 2001: Population dynamics of Ornithodiplostomum ptychocheilus metacercariae in fathead minnows (Pimephales promelas) from four Northern-Alberta lakes. J. Parasitol. 87: 744-748.

Schмidt G.D. 1992: Essentials of Parasitology. Fifth Edition. William C. Brown Publishers, Dubuque, 294 pp.

Sнaн H.B. 2010: Community Structure of Fish Parasites and their Intermediate Hosts in Relation to Trophic Conditions of Lakes. PhD thesis, University of Kashmir, Srinagar, 223 pp.

Vidal-Martínez V.M., Pech D., Sures B., Purucker S.T., PouLIN R. 2010: Can parasites really reveal environmental impact? Trends Parasitol. 26: 44-51.

VOLTERRA V. 1926: Fluctuations in the abundance of a species considered mathematically. Nature 118: 558-560.

Weesner F.M. 1960: General Zoological Microtechniques. Williams and Wilkins Company, Baltimore, Maryland, $230 \mathrm{pp}$.

Wetzel R.G. 2001: Limnology: Lakes and River Ecosystems. Third Edition. Academic Press, San Diego, California, 850 pp.

WISNIEWISKI W.L. 1958: Characterisation of the parasitofauna of a eutrophic lake. Acta Parasitol. Pol. 6: 1-64.

Yousuf A.R., Firdous G., Peerzada K.J. 2002: Ecology and feeding biology of commercially important cyprinid fishes of Anchar lake, Kashmir, with a note on their conservation. In: A.K. Pandit (Ed.), Natural Resources of Western Himalaya. Valley Book House, Srinagar, pp. 243-272.

Zutshi D.P., Subla B.A., Khan M.A., Wanganeo A. 1980: Comparative limnology of nine lakes of Jammu and Kashmir Himalayas. Hydrobiologia 72: 101-112.

Accepted 19 November 2012 